\title{
Systematic review on use, cost and clinical efficacy of automated decontamination devices
}

\author{
Stephanie J. Dancer ${ }^{1,2^{*}}$ (D) and Marco-Felipe King ${ }^{3}$
}

\begin{abstract}
Background: More evidence is emerging on the role of surface decontamination for reducing hospital-acquired infection (HAl). Timely and adequate removal of environmental pathogens leads to measurable clinical benefit in both routine and outbreak situations.

Objectives: This systematic review aimed to evaluate published studies describing the effect of automated technologies delivering hydrogen peroxide (H202) or ultra-violet (UV) light on HAl rates.

Methods: A systematic review was performed using relevant search terms. Databases were scanned from January 2005 to March 2020 for studies reporting clinical outcome after use of automated devices on healthcare surfaces. Information collected included device type, overall findings; hospital and ward data; study location, length and size; antimicrobial consumption; domestic monitoring; and infection control interventions. Study sponsorship and duplicate publications were also noted.
\end{abstract}

Results: While there are clear benefits from non-touch devices in vitro, we found insufficient objective assessment of patient outcome due to the before-and-after nature of 36 of 43 (84\%) studies. Of 43 studies, 20 (47\%) used hydrogen peroxide (14 for outbreaks) and 23 (53\%) used UV technology (none for outbreaks). The most popular pathogen targeted, either alone or in combination with others, was Clostridium difficile (27 of 43 studies: 63\%), followed by methicillin-resistant Staphylococcus aureus (MRSA) (16 of 43: 37\%). Many owed funding and/or personnel to industry sponsorship (28 of 43: 65\%) and most were confounded by concurrent infection control, antimicrobial stewardship and/or cleaning audit initiatives. Few contained data on device costs and rarely on comparable costs (1 of 43: 2\%). There were expected relationships between the country hosting the study and location of device companies. None mentioned the potential for environmental damage, including effects on microbial survivors.

Conclusion: There were mixed results for patient benefit from this review of automated devices using H202 or UV for surface decontamination. Most non-outbreak studies lacked an appropriate control group and were potentially compromised by industry sponsorship. Concern over HAl encourages delivery of powerful disinfectants for eliminating pathogens without appreciating toxicity or cost benefit. Routine use of these devices requires justification from standardized and controlled studies to understand how best to manage contaminated healthcare environments.

Keywords: Decontamination, Environment, Hospital-acquired infection, Ultraviolet light, Hydrogen peroxide, Toxicity, Cost

${ }^{*}$ Correspondence: stephanie.dancer@lanarkshire.scot.nhs.uk

${ }^{1}$ Department of Microbiology, Hairmyres Hospital, NHS, Lanarkshire G75 8RG, Scotland, UK

Full list of author information is available at the end of the article

\section{Introduction}

Hospital-based cleaning and disinfection of environmental surfaces is now recognised as a crucial component of infection prevention and control [1]. This has generated interest in a range of automated decontamination technologies over the past decade. So-called 'no-touch' original author(s) and the source, provide a link to the Creative Commons licence, and indicate if changes were made. The images or other third party material in this article are included in the article's Creative Commons licence, unless indicated otherwise in a credit line to the material. If material is not included in the article's Creative Commons licence and your intended use is not permitted by statutory regulation or exceeds the permitted use, you will need to obtain permission directly from the copyright holder. To view a copy of this licence, visit http://creativecommons.org/licenses/by/4.0/. The Creative Commons Public Domain Dedication waiver (http://creativeco mmons.org/publicdomain/zero/1.0/) applies to the data made available in this article, unless otherwise stated in a credit line to the data. 
devices disperse chosen microbiocidal products into the healthcare environment in order to disinfect surfaces and reduce the risk of hospital-acquired infection (HAI) [2]. Given that the agents utilised by these devices are toxic to humans, the mobile equipment designed to deliver them are necessarily controlled through remote access. Chemical products include chlorine dioxide, hydrogen peroxide and ozone in gaseous form; and peracetic acid, quaternary ammonium compounds and hydrogen peroxide as aerosols [1-3]. Another compound, peroxone, combines hydrogen peroxide and ozone to create a dual system with enhanced oxidation [4]. Alternative decontamination technology makes use of ultra-violet (UV) light, which is produced using either mercury or xenon bulbs $[1-3]$. There are multiple reports describing the in vitro effect of these systems, but studies investigating the clinical impact on hospital patients tend to favour devices dispelling either hydrogen peroxide or UV light. It was decided to review these specific technologies in order to further examine their effects on clinical benefit and cost.

Most UV devices use low-pressure mercury gas bulbs to generate UV-C light with a targeted wavelength of $254 \mathrm{~nm}$; pulsed xenon devices produce a broader spectrum of UV light in short pulses with a target wavelength of 200-315 nm [3]. UV light breaks DNA bonds resulting in death of microorganisms, including spores [5]. Aerosolized hydrogen peroxide systems utilize 3-7\% hydrogen peroxide, sometimes with silver ions, with particle sizes ranging from 2 to $12 \mu \mathrm{m}$ [6]. These particles are released into a room, followed by passive aeration. The vapour system is based on micro-condensation, which allows the vaporization of concentrated (30-35\%) hydrogen peroxide under controlled humidity [6].

While there is no doubt over the in vitro capacity of these technologies to eliminate surface pathogens, there are concerns over practicalities of use, toxicity and costbenefits in vivo $[7,8]$. Not all studies report complete removal of specific pathogen reservoirs or, indeed, significant reductions in HAI rates. It is clear that prior removal of dirt is essential before deployment of these devices [9-11]. There is additional concern over the data provided since selective reporting from quasi-experimental studies does not necessarily offer a balanced view of the technology evaluated [12]. Some studies are conflicted by ongoing or newly introduced infection prevention or cleaning interventions during the study period; others report, or fail to report, concurrent or newly introduced antimicrobial stewardship initiatives [13, 14]. Many studies omit mention of environmental monitoring, cleaning efficacy or even baseline cleaning protocols $[7,14]$. Furthermore, studies using these devices do not necessarily disclose sources of funding or declare potential conflicts from industry sponsorship, including the provision of training, equipment, report writing and/or personnel $[1,15]$.

The aim of this systematic review is to critically assess study design, confounders, costs and overall clinical outcome for decontamination devices using hydrogen peroxide or UV light for surfaces in the healthcare environment. Given the recent increase in use of these devices, it is timely to offer objective comments on real life impact for patients and healthcare budgets [7].

\section{Methods}

A systematic review was performed using relevant search terms: [hospital or healthcare] + [disinfection or decontamination] + [hydrogen peroxide or ultraviolet light] (Fig. 1). The databases employed were PubMed, CINAHL, CDSR, DARE and EMBASE from Jan 2005 to March 2020 for studies evaluating automated device technology using ultraviolet microbiocidal light (UV) or hydrogen peroxide (H202) in healthcare facilities for contamination on surfaces \pm air using indicator pathogens \pm aerobic colony counts; cost of technology; and HAI rates for Clostridium difficile, methicillin-resistant Staphylococcus aureus (MRSA), vancomycin-resistant enterococci (VRE), coliforms (Escherichia coli, Klebsiella pneumoniae, Enterobacter spp., Serratia spp.), Pseudomonas spp., Acinetobacter spp., and generic multidrug-resistant organisms (MDROs) including extended-spectrum-beta-lactamase producing coliforms (ESBLs). Studies describing in vitro; in situ; experimental and/or surface effects of non-touch technologies without concurrent data on patient impact were scanned before exclusion, along with non-English papers, posters and conference reports (Fig. 1). Hospital location, types, study ward/unit, study length and size, antimicrobial consumption (total; specific classes); domestic monitoring, infection control interventions and other variables that might impact on the results were noted. Specialist healthcare environments such as outpatients, pharmacies and clean rooms were excluded, as were articles describing microbiological impact of automated devices on specific items of equipment. Published data was checked for duplicate or linked publications, funding, sponsors and industry involvement if acknowledged.

\section{Statistical analysis}

Statistical review and analysis was applied to common data presented in selected device papers. Risk of bias was assessed for each study by evaluating study design, methodological consistency, infection control confounders, population and study unit heterogeneity, sampling bias, outcome evaluation, involvement of sponsor and selective reporting. Power calculations and overall numbers were examined against reported significance values. 


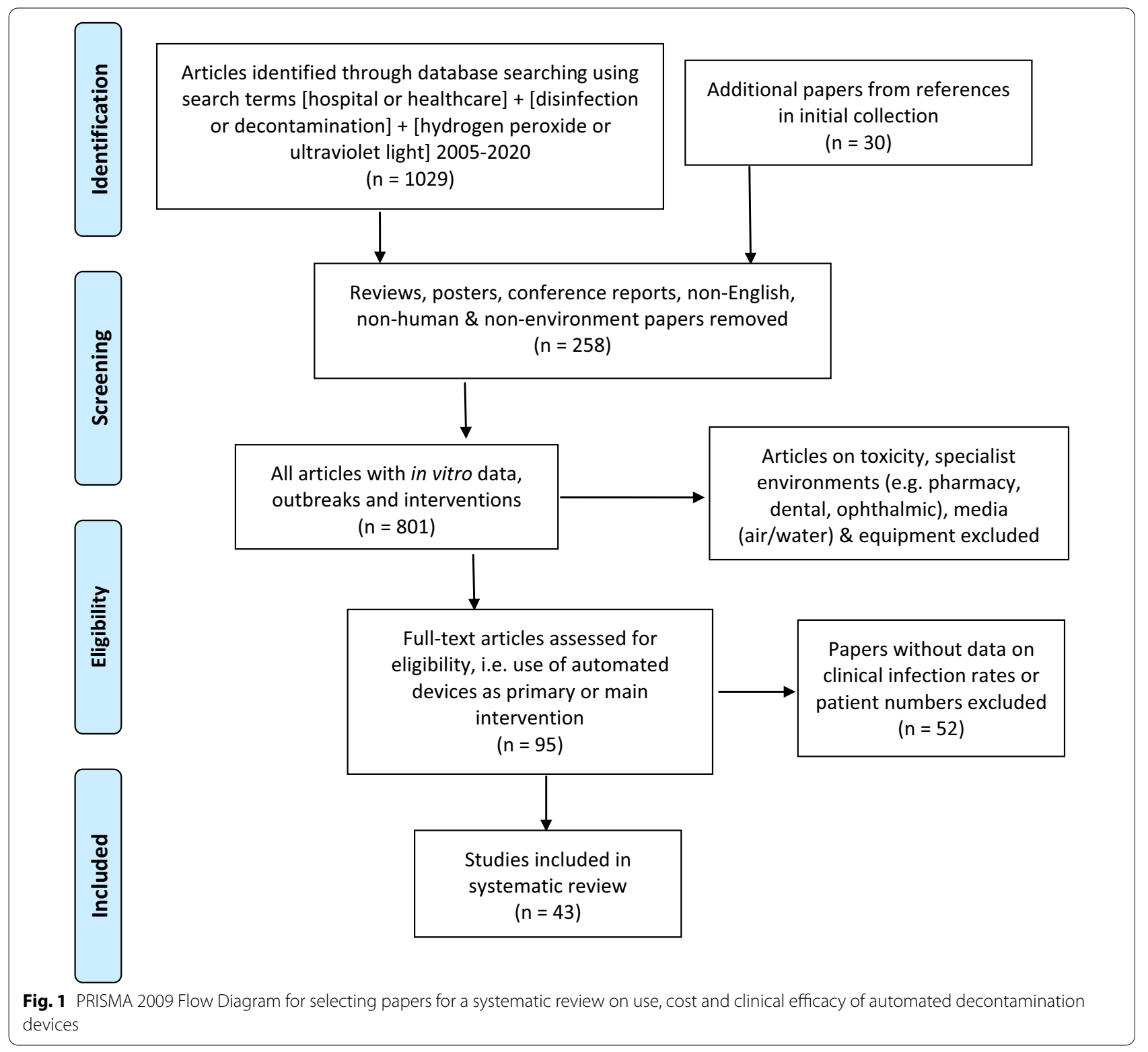

\section{Results}

\section{Study demographics}

There were a total of 43 studies presenting the effects on HAI rates from automated devices delivering either hydrogen peroxide or UV light (Table 1; Figs. 1, 2) [1658]. These were published between 2005 and 2020 and include brief reports and letters describing either intervention or outbreak control studies involving different hospitals from eight countries in the developed world. Of these, 20 (47\%) used some form of hydrogen peroxide delivery (14 for outbreaks) and 23 (53\%) used UV technology (none for outbreaks). Over half the papers (28; $65 \%$ ) originated from the USA, with six describing the effects of hydrogen peroxide devices [37, 38, 47, 49, 55, 57] and 22 utilising UV technology (Fig. 3) [16, 18, 21-31, 34-36, 39-41, 43, 48, 50]. Five (12\%) studies were based in the UK, all using hydrogen peroxide, [32, 44, 53, 56, $58]$ and three $(7 \%)$ others using hydrogen peroxide were performed in France (Fig. 4) [45, 46, 51]. Two (5\%) studies each using hydrogen peroxide originated from Spain $[19,33]$ and The Netherlands, $[20,54]$ and there was one (2\%) study each from Japan (UV) [17], Poland (hydrogen peroxide) [52] and Tasmania (hydrogen peroxide) [42]. There were no studies reporting use of UV in Europe.

Most (36: 84\%) were before-and-after studies, including 14 (33\%) outbreak interventions [19, 20, 33, 44-46, 
Table 1 Data from 43 original or outbreak studies reporting patient benefit from use of UV or H202 automated devices

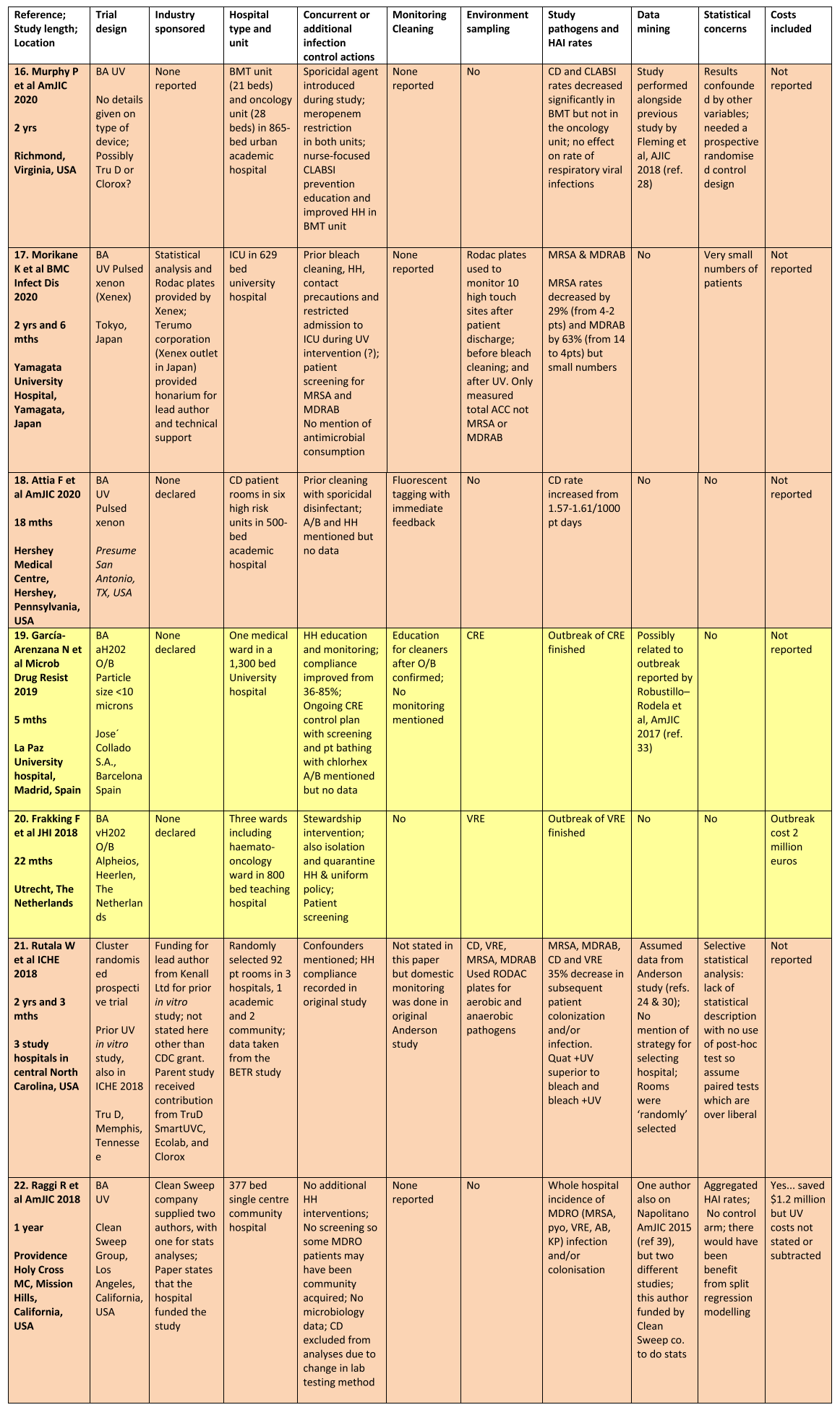

51-58]; three (7\%) originated from the same cluster randomised prospective study (Benefits of Enhanced Terminal Room Disinfection: BETR study) [21, 24, 30] and the remaining four $(9 \%)$ were controlled studies, [25, 27, 47] with one interrupted time series that included a control arm [31]. 
Table 1 (continued)

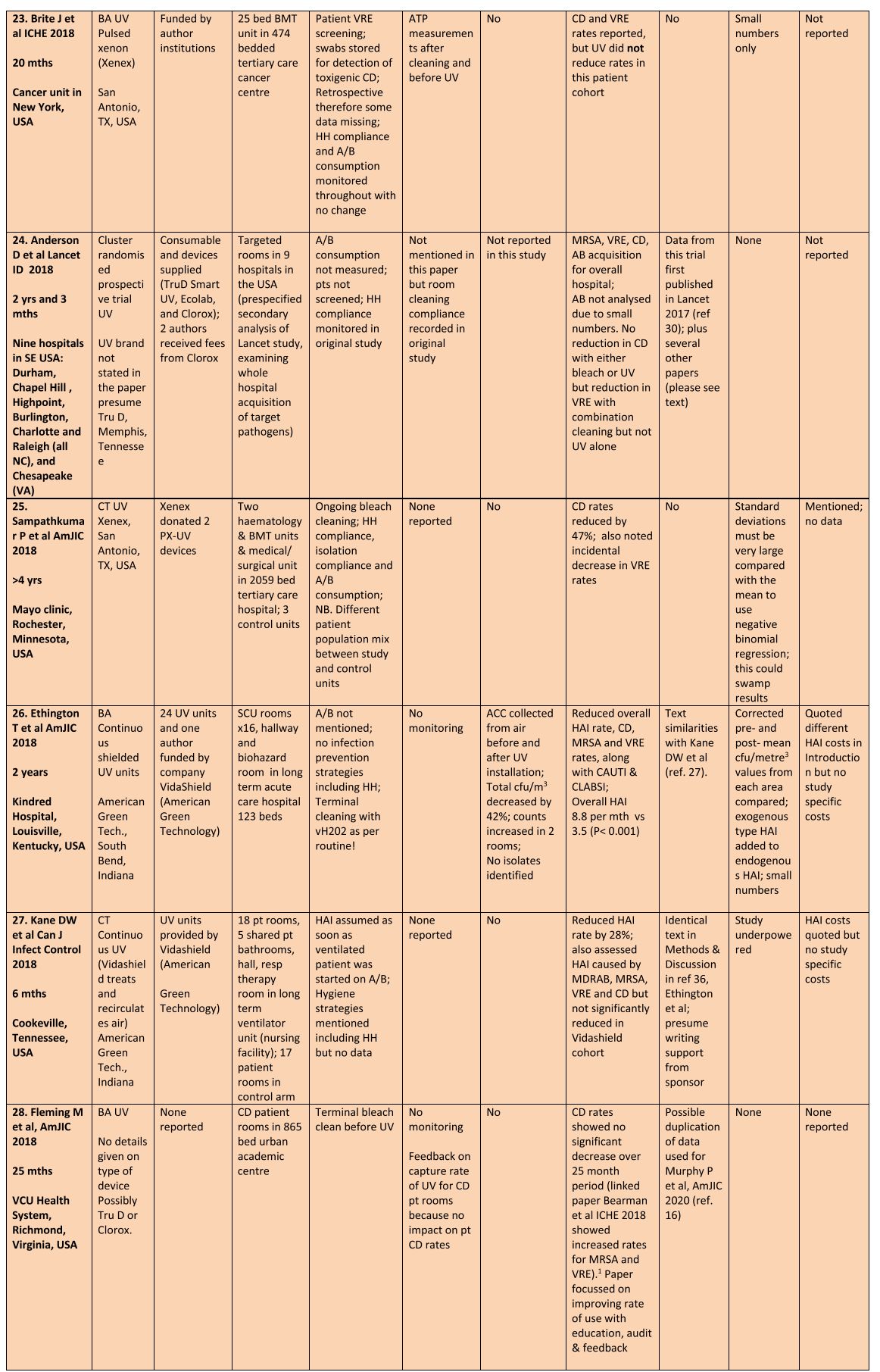

There were many different types of hospitals involved in assessing decontamination devices, mostly university and tertiary hospitals with 400-2000 beds; and some district general or community hospitals (100-400 beds) or long term care hospitals (50-170 beds). There were two studies performed exclusively in burns unit [34, 51]; these, along with others, did not indicate the type of host hospital. Other specialist units included intensive care $[17,26,32,33,35,39,40,45,46,52,54]$; neonatal [58]; biohazard [26] and treatment rooms [51]; bone marrow transplant $[16,23,25]$; haematology and/or oncology $[16,20,25,31]$; respiratory therapy room [27]; operating theatres [36, 43, 48]; dialysis unit [43]; stroke rehabilitation [44]; accident and emergency [48]; and three studies 
Table 1 (continued)

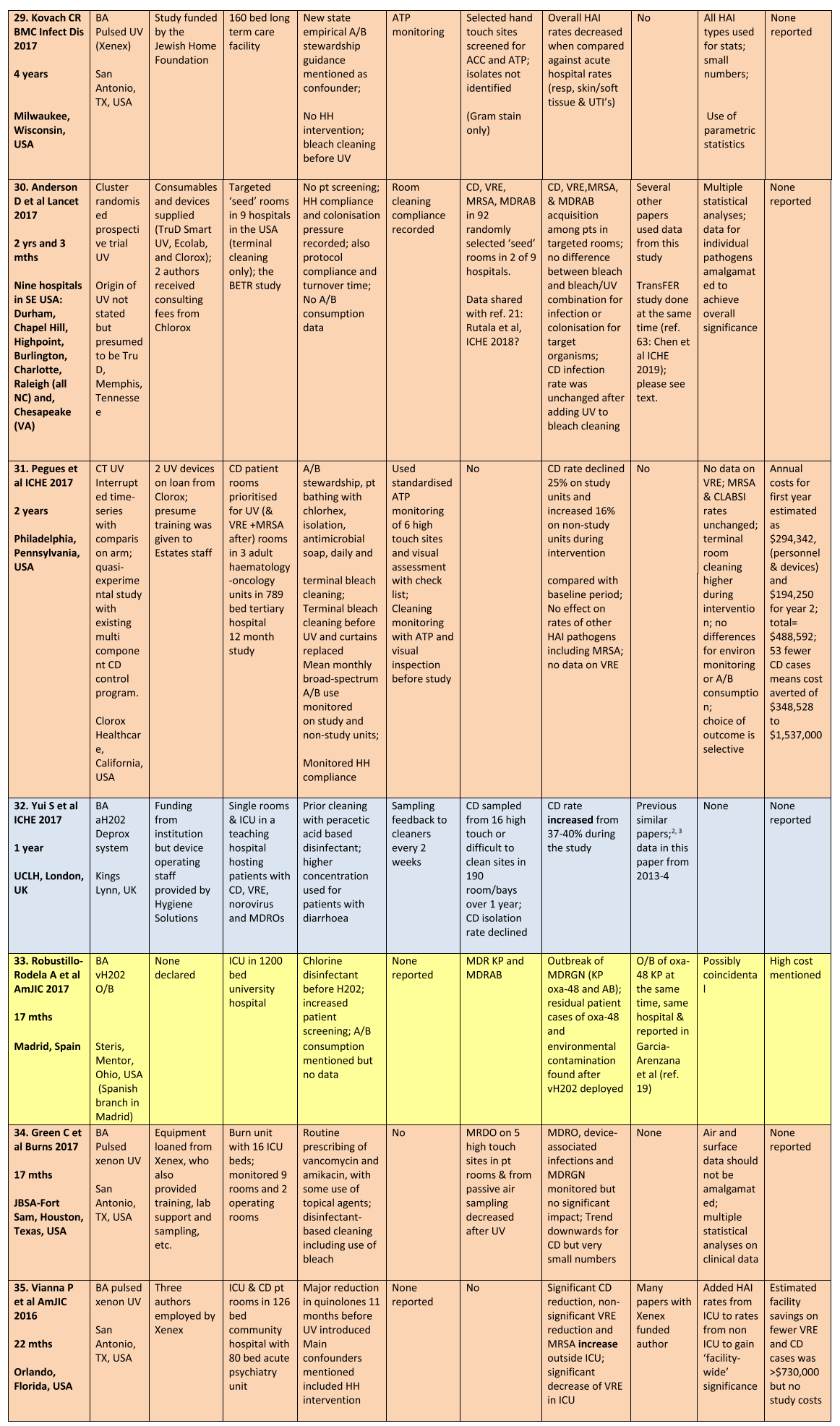

mentioned bathrooms [27] and/or communal areas [26, $27,41]$.

Figure 2 shows the year of publication for each study. From 2005 to 2014, most of the studies employed hydrogen peroxide devices (14 of 17: 82\%) whereas from 2015 to 2020 , the studies predominantly focussed on UV devices (20 of 26: 77\%). The total length of the studies, i.e. period of time over which data was 
Table 1 (continued)

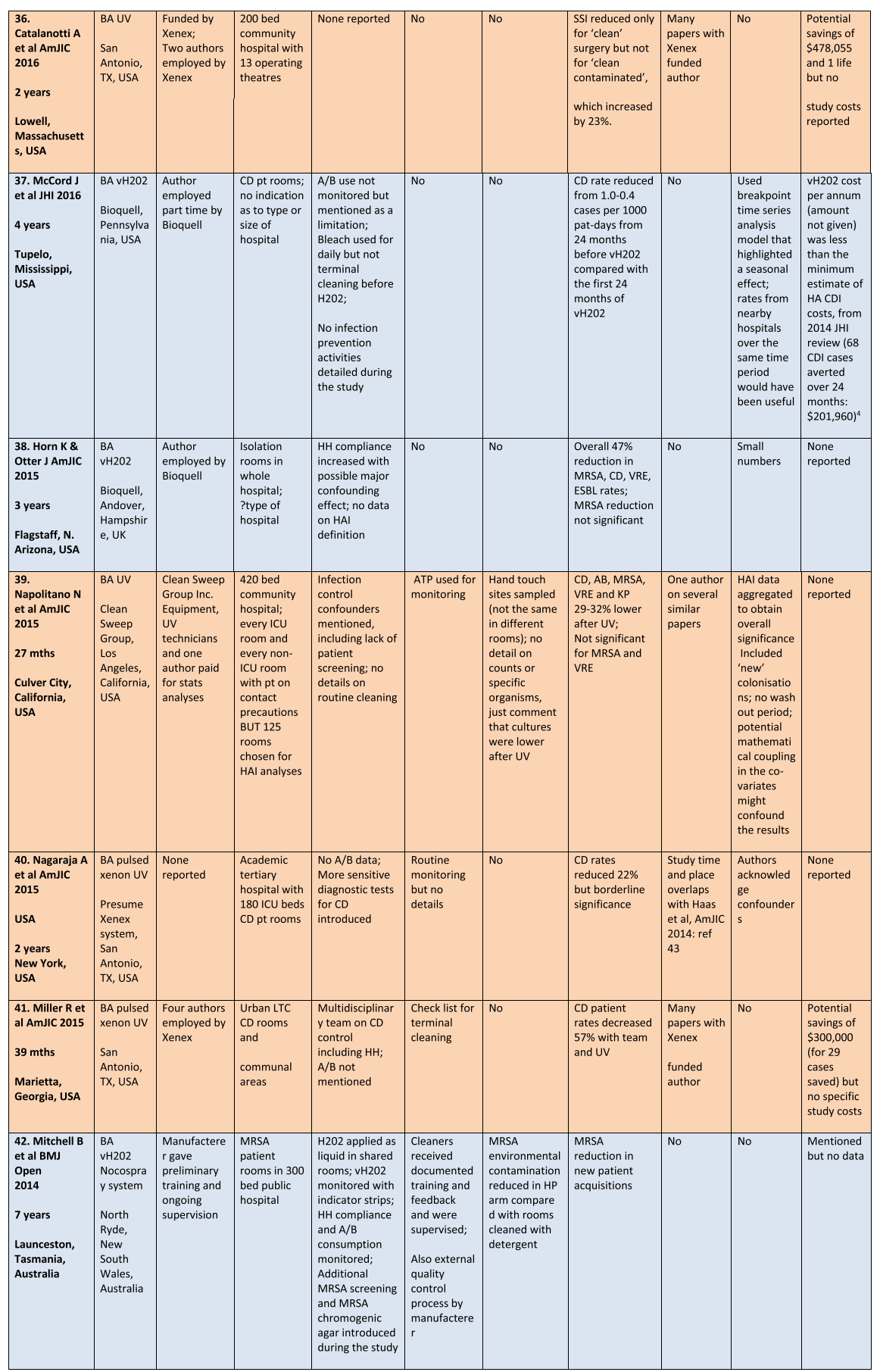

gathered, ranged from 18 weeks to 3 years for outbreaks $(n=14)$, with a median time of $17-18$ months and an average duration of 16 months. For intervention studies $(n=29)$, the total length of time ranged from 6 months to 7 years; the median time was 27 months and the average was 30 months (Table 1).

\section{Effect on HAI rates}

All 43 studies presented an assessment of chosen technology on HAI rates, which described the effect on one specific pathogen or a combination; from Clostridium difficile, methicillin-resistant Staphylococcus aureus (MRSA), multi-drug resistant Gram-negative coliforms 
Table 1 (continued)

\begin{tabular}{|c|c|c|c|c|c|c|c|c|c|c|}
\hline $\begin{array}{l}\text { 43. Haas J et } \\
\text { al AmJIC } 2014 \\
4 \text { years } 4 \text { mths } \\
\text { New York, } \\
\text { USA }\end{array}$ & \begin{tabular}{|l} 
BA UV \\
Pulsed \\
xenon \\
Xenex \\
system \\
San \\
Antonio, \\
TX, USA
\end{tabular} & \begin{tabular}{|l|} 
None \\
declared
\end{tabular} & \begin{tabular}{|l|} 
Patients on \\
contact \\
precautions \\
rooms in 643 \\
bed \\
academic \\
tertiary \\
hospital; also \\
operating \\
theatres, \\
dialysis unit \\
and burn \\
patient \\
rooms
\end{tabular} & \begin{tabular}{|l|} 
Daily and \\
terminal \\
cleaning with \\
bleach; \\
paediatric \\
rooms were \\
cleaned with \\
quat; \\
introduced ATP \\
and DAZO \\
during study; \\
possible A/B \\
use as \\
confounder
\end{tabular} & \begin{tabular}{|l|} 
Monitoring \\
cleaning \& \\
cleanliness \\
using both \\
DAZO and \\
ATP; \\
used a check \\
list; \\
introduced \\
new \\
environment \\
al services \\
contractor
\end{tabular} & No & \begin{tabular}{|l|} 
CD, MRSA, VRE, \\
MDRGN showed \\
overall 20\% \\
reduction in HAI \\
rates during 22 \\
month study; \\
none achieved \\
individual \\
significance
\end{tabular} & No & \begin{tabular}{|l} 
Amalgamat \\
ed rates of \\
different \\
pathogens \\
to obtain \\
overall \\
significance
\end{tabular} & \begin{tabular}{|l|l}
$\begin{array}{l}\text { None } \\
\text { reported }\end{array}$ \\
\end{tabular} \\
\hline $\begin{array}{l}\text { 44. Best EL et } \\
\text { al J Hosp } \\
\text { Infect } 2014 \\
20 \text { mths } \\
\text { Leeds, UK }\end{array}$ & \begin{tabular}{|l|} 
BA \\
aH202 \\
O/B \\
Deprox \\
system \\
Kings \\
Lynn, UK
\end{tabular} & \begin{tabular}{|l|} 
Devices \\
supplied by \\
Hygiene \\
Solutions
\end{tabular} & \begin{tabular}{|l|}
30 bed \\
Stroke rehab \\
unit in 2000 \\
bed tertiary \\
hospital
\end{tabular} & \begin{tabular}{|l|} 
A/B review, \\
patient cohorts, \\
HH education \\
and staff \\
training before \\
and during \\
study; \\
Detergent \& \\
chlorine deep \\
clean before \\
H202
\end{tabular} & \begin{tabular}{|l|} 
No \\
monitoring; \\
staff training \\
before the \\
study
\end{tabular} & $\begin{array}{l}\text { CD recovered } \\
\text { using Polywipe } \\
\text { sponges from } \\
\text { high, medium } \\
\text { and low } \\
\text { placed sites; } \\
\text { genotyping } \\
\text { using MVLA } \\
\text { and STRD }\end{array}$ & \begin{tabular}{|l} 
CD patients \\
decreased from \\
20 to 7 from 10 \\
months before \\
H202 to 10 \\
months after; \\
concluded that \\
H202 might be \\
useful for high \\
incidence of CD
\end{tabular} & No & $\begin{array}{l}\text { Confoundin } \\
\mathrm{g} \\
\text { exposures }\end{array}$ & \begin{tabular}{|l|} 
Briefly \\
mentioned: \\
H2O2 cost \\
€7000 per \\
ward. Is \\
cost benefit \\
sufficient \\
to employ \\
H202?
\end{tabular} \\
\hline $\begin{array}{l}\text { 45. Alfandari S } \\
\text { et al Med Mal } \\
\text { Infect } 2014 \\
27 \text { weeks } \\
\text { Tourcoing, } \\
\text { France }\end{array}$ & \begin{tabular}{|l|} 
BA \\
aH202 \\
O/B \\
No details \\
on type of \\
H2O2
\end{tabular} & \begin{tabular}{|l|}
$\begin{array}{l}\text { None } \\
\text { declared }\end{array}$ \\
\end{tabular} & $\begin{array}{l}16 \text { bed ICU in } \\
400 \text { bed in } \\
\text { University } \\
\text { hospital }\end{array}$ & \begin{tabular}{|l|} 
Ongoing \\
screening \\
enhanced; BP \\
cuffs implicated \\
even after H202 \\
exposure; \\
Staff cohorting, \\
HH education, \\
patient isolation \\
and limited carb \\
consumption; \\
External audit of \\
IC actions; \\
Double \\
disinfection of \\
patient rooms \\
\end{tabular} & No & MDRAB & \begin{tabular}{|l|} 
Two prolonged \\
O/Bs 4 weeks \\
apart despite \\
H202 \& \\
additional \\
infection control \\
activities
\end{tabular} & No & No & \begin{tabular}{|l} 
High cost of \\
outbreak \\
mentioned \\
but no data
\end{tabular} \\
\hline $\begin{array}{l}\text { 46. Landelle C } \\
\text { et al ICHE } \\
2013 \\
18 \text { mths } \\
\text { Paris, France }\end{array}$ & \begin{tabular}{|l} 
BA \\
v/a H2O2 \\
O/B \\
Sterinis- \\
Sterusil, \\
Gloster \\
Sante \\
Europe, \\
Toulouse, \\
France for \\
dry-mist \\
H202; \\
Bioquell \\
for \\
vH202, \\
presume \\
Andover, \\
Hampshir \\
e, UK, or \\
Marne, \\
France
\end{tabular} & \begin{tabular}{|l|} 
None \\
declared
\end{tabular} & $\begin{array}{l}860 \text { beds in } \\
\text { university } \\
\text { hospital with } \\
5 \text { ICUs }\end{array}$ & \begin{tabular}{|l|} 
ICU patients \\
screened for \\
MDRGN \\
including AB; \\
Unit closure; \\
Cohorting in \\
isolation unit \\
with dedicated \\
staff; $H$ H and \\
contact \\
precautions; \\
chlorhex baths \\
for patients; \\
Twice daily \\
cleaning with \\
disinfectant and \\
terminal clean \\
with H202; \\
Bleach cleaning \\
of sinks; \\
No AB data
\end{tabular} & \begin{tabular}{|l} 
None \\
reported
\end{tabular} & $\begin{array}{l}\text { Environmental } \\
\text { screening } \\
\text { before and } \\
\text { after H202 } \\
\text { incl. sinks } \\
\text { faucets and } \\
\text { water } \\
\text { splashes; also } \\
\text { air sampling } \\
\text { for MDRAB }\end{array}$ & $\begin{array}{l}18 \text { month } \\
\text { outbreak of } \\
\text { MDRAB }\end{array}$ & \begin{tabular}{|l|}
$\mathrm{O} / \mathrm{B}$ \\
recurred \\
several \\
times
\end{tabular} & \begin{tabular}{|l|l} 
No wash \\
out period
\end{tabular} & \begin{tabular}{|l}
$\begin{array}{l}\text { None } \\
\text { reported }\end{array}$ \\
int
\end{tabular} \\
\hline $\begin{array}{l}\text { 47. Passaretti } \\
\text { C et al Clin } \\
\text { Infect Dis } \\
2013 \\
30 \text { mths } \\
\text { John Hopkins, } \\
\text { Baltimore, } \\
\begin{array}{l}\text { Maryland, } \\
\text { USA }\end{array}\end{array}$ & $\begin{array}{l}\text { Prospecti } \\
\text { ve cohort } \\
\text { randomis } \\
\text { ed control } \\
\text { study } \\
\text { vH202 } \\
\text { Bioquell } \\
\text { system, } \\
\text { Horsham, } \\
\text { Pennsylva } \\
\text { nia, USA }\end{array}$ & \begin{tabular}{|l|} 
Bioquell \\
provided \\
devices and \\
trained \\
personnel; \\
one author \\
employed by \\
Bioquell
\end{tabular} & \begin{tabular}{|l|} 
Patient \\
rooms in 6 \\
high risk \\
units in 994 \\
bed tertiary \\
care hospital \\
H202 use at \\
beginning of \\
study and \\
then for \\
terminal \\
cleaning for \\
pts with \\
MDROs \\
Mon-Fri
\end{tabular} & $\begin{array}{l}\text { Patients in two } \\
\text { of } 3 \text { control } \\
\text { units were also } \\
\text { involved in a } \\
\text { trial of } \\
\text { chlorhexidine } \\
\text { bathing and } \\
\text { were excluded } \\
\text { from this study; } \\
\text { All pts screened } \\
\text { for VRE and } \\
\text { MRSA; } \\
\text { Cleaning with } \\
\text { quat; and liquid } \\
\text { H202 used for } \\
\text { rooms of CD pts }\end{array}$ & $\begin{array}{l}\text { Sampling } \\
\text { data fed } \\
\text { back to } \\
\text { cleaning staff }\end{array}$ & \begin{tabular}{|l} 
CD, VRE, \\
MRSA, \\
MDRGN with \\
results fed \\
back to staff \\
Frequency of \\
room \\
contamination \\
decreased \\
from $0.6 \%$ \\
to $0 \%$ \\
Sampling \\
methods not \\
quantified.
\end{tabular} & \begin{tabular}{|l|} 
CD, VRE, MRSA, \\
MDRGN \\
Risk of acquiring \\
CD was reduced \\
but not \\
significant \\
(incidence rate \\
of CD down \\
from 2.1 to \\
$0.7 / 1000$ pat \\
days) (P $=0.19$ ) \\
Risk not \\
significantly \\
reduced for \\
either MRSA or \\
MDRGN; \\
Reduction in \\
risk of acquiring \\
MDRO \\
attributed to \\
VRE data, which \\
was endemic in \\
this institution
\end{tabular} & No & \begin{tabular}{|l|} 
Overall \\
statistical \\
significance \\
came from \\
decrease in \\
VRE not \\
MRSA, CD \\
or MDRGN \\
\end{tabular} & \begin{tabular}{|l|} 
No costs \\
reported; \\
28 MDRO \\
transmissio \\
ns were \\
prevented \\
in 3 high \\
risk units in \\
this \\
hospital \\
over 18 \\
months
\end{tabular} \\
\hline $\begin{array}{l}\text { 48. Levin J et } \\
\text { al AmJIC } 2013 \\
4 \text { years } \\
\text { Northampton, } \\
\text { Massachusett } \\
\text { s, USA }\end{array}$ & $\begin{array}{l}\text { BA pulsed } \\
\text { xenon UV } \\
\text { Xenex } \\
\text { system } \\
\text { San } \\
\text { Antonio, } \\
\text { TX, USA }\end{array}$ & \begin{tabular}{|l|} 
None \\
reported
\end{tabular} & \begin{tabular}{|l|}
$140-$ bed \\
acute \\
care \\
community \\
hospital, \\
CD patient \\
rooms; also \\
operating \\
theatres, \\
A\&E, etc
\end{tabular} & $\begin{array}{l}\text { Quinolone } \\
\text { consumption } \\
\text { reduced before } \\
\text { and during } \\
\text { intervention; } \\
\text { Rooms cleaned } \\
\text { with chlorine } \\
\text { products }\end{array}$ & $\begin{array}{l}\text { No } \\
\text { monitoring } \\
\text { during the } \\
\text { study; } \\
\text { Cleaners } \\
\text { received an } \\
\text { educational } \\
\text { initiative for } \\
2 \text { years } \\
\text { before the } \\
\text { intervention }\end{array}$ & \begin{tabular}{|l|} 
No \\
\end{tabular} & $\begin{array}{l}53 \% \text { decrease of } \\
\text { hospital- } \\
\text { acquired CD } \\
\text { incidence (from } \\
9.46 \text { to } 4.45 \\
110,000 \\
\text { pat-days) (P } \\
=0.01)\end{array}$ & No & No & \begin{tabular}{|l|} 
Overall \\
costs not \\
supplied; \\
rent for 2 \\
units cost \\
$\$ 5000$ per \\
month
\end{tabular} \\
\hline
\end{tabular}


Table 1 (continued)

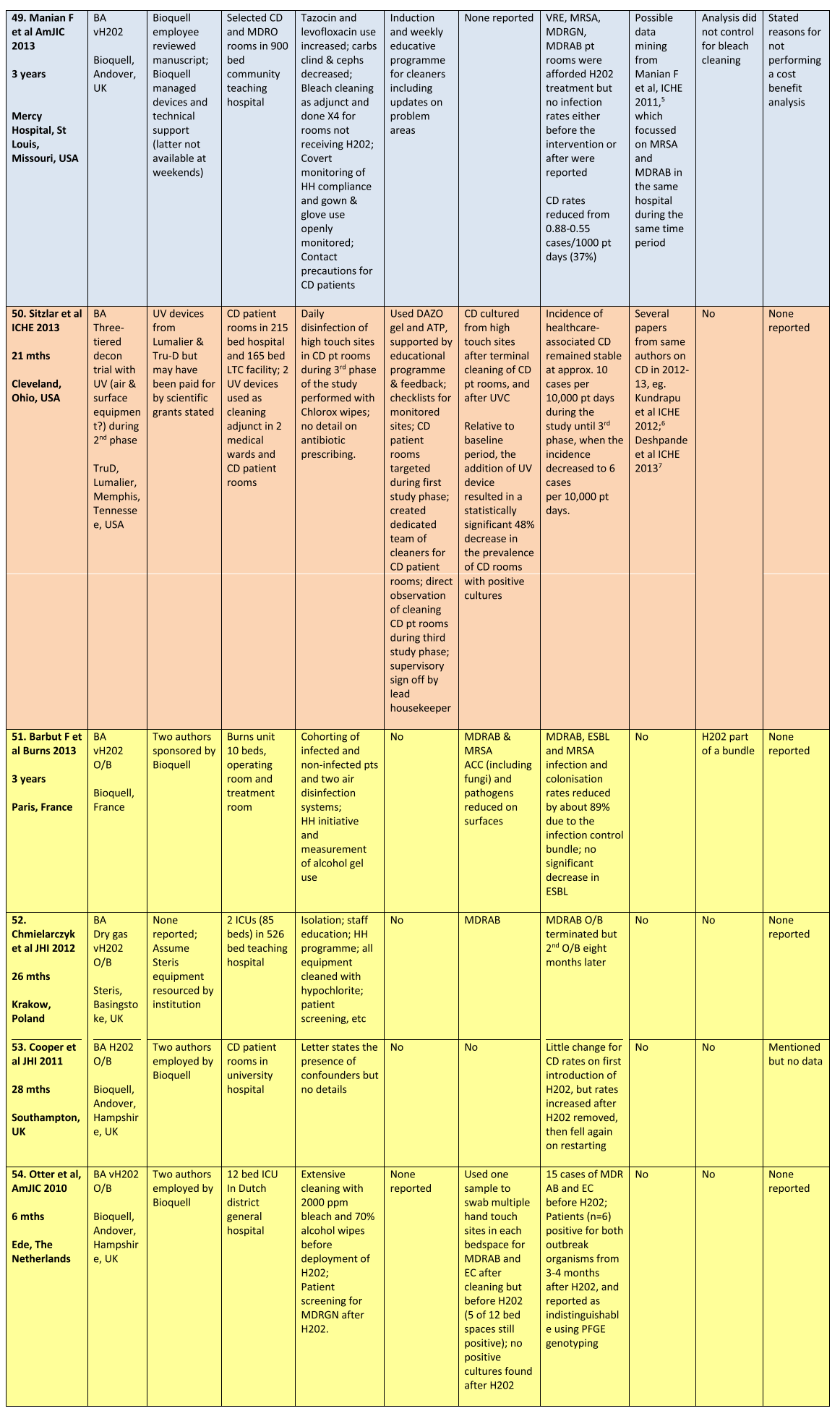

(MDRGN), multi-drug resistant Acinetobacter (MDRA), Pseudomonas aeruginosa, vancomycin-resistant enterococci (VRE), combined multiply drug resistant organisms
(MDROs); or overall HAI rates; or surgical site, catheter and device infection rates (Table 1). The most popular pathogen to control with automated devices, either alone, 
Table 1 (continued)

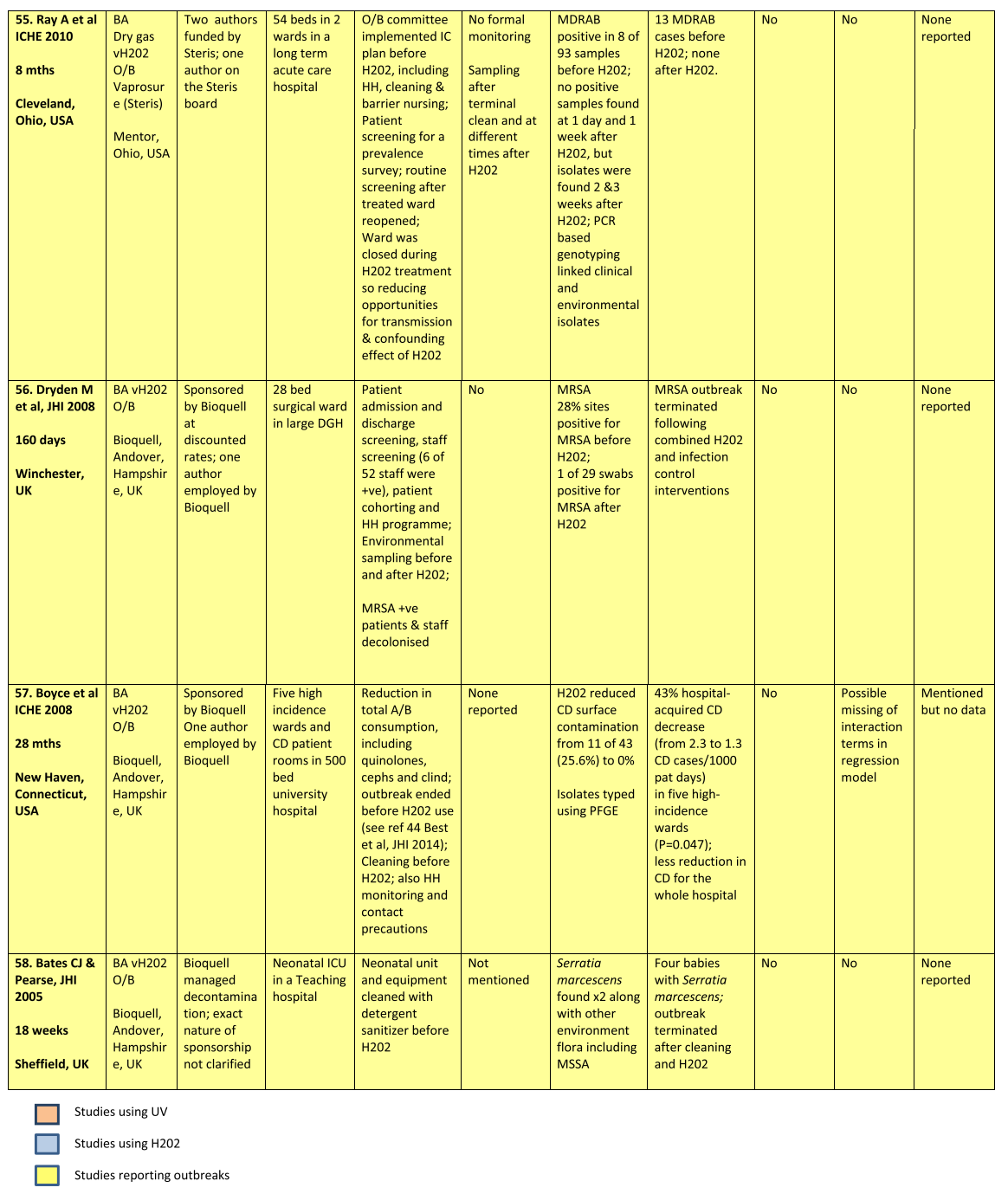

Key: BA, before-and-after; UV, ultraviolet light; $\mathrm{H} 202$, hydrogen peroxide (v=vapourised; a=aerosolized); pt, patient; BMT, bone marrow transplant; $C D$, Clostridium difficile; CLABSI, central line-associated blood stream infection; ICU, intensive care unit; MRSA, methicillin-resistant Staphylococcus aureus; MDRAB, multidrug resistant Acinetobacter baumannii; ACC, aerobic colony counts; O/B, outbreak; $\mathrm{HH}$, hand hygiene; VRE, vancomycin-resistant enterococci; CRE, carbapenem-resistant enterobacteriaceae; chlorhex, chlorhexidine; $A / B$, antibiotics; Quat, quaternary ammonium compound; MDR(O), multidrug resistant (organisms); pyo, pseudomonas; $\mathrm{AB}$, Acinetobacter baumannii; $\mathrm{KP}$, Klebsiella pneumoniae; $\mathrm{CT}$, controlled trial; $\mathrm{SCU}$, special care unit; cfu, colony forming units; HAl, hospital-acquired infection; resp, respiratory; ATP, adenosine triphosphate; UTI, urinary tract infection; MDRGN, multidrug resistant Gram-negative organisms; SSI, surgical site infections; ESBL, extended spectrum beta-lactamase producing coliforms; LTC, long term care; DAZO'M, fluorescent gel; A/E, accident and emergency; carbs, carbapenems; clin, clindamycin; cephs, cephalosporins; EC, Enterobacter cloacae; PFGE, pulsed field electrophoresis; PCR, polymerase chain reaction; IC, infection control

Additional references:

1. Bearman G, Abbas S, Masroor N, Sanogo K, Vanhoozer G, Cooper K, Doll M, Stevens MP, Edmond MB. Impact of Discontinuing Contact Precautions for Methicillin-Resistant Staphylococcus aureus and Vancomycin-Resistant Enterococcus: An Interrupted Time Series Analysis. Infect Control Hosp Epidemiol 2018; 39(6): 676-682.

2. Ali S, Muzslay M, Wilson P. A Novel quantitative sampling technique for detection and monitoring of Clostridium difficile contamination in the clinical environment. J Clin Microbiol 2015; 53: 2570-2574.

3. Ali S, Muzslay M, Bruce M, Jeanes A, Moore G, Wilson AP. Efficacy of two hydrogen peroxide vapour aerial decontamination systems for enhanced disinfection of meticillin-resistant Staphylococcus aureus, Klebsiella pneumoniae and Clostridium difficile in single isolation rooms. J Hosp Infect 2016; 93: 70-77.

4. Gabriel L, Beriot-Mathiot A. Hospitalization stay and costs attributable to Clostridium difficile infection: a critical review. J Hosp Infect 2014; 88(1): 12-21

5. Manian FA, Griesenauer S, Senkel D, et al. Isolation of Acinetobacter baumannii complex and methicillin-resistant Staphylococcus aureus from hospital rooms following terminal cleaning and disinfection: can we do better? Infect Control Hosp Epidemiol 2011; 32(7): 667-672.

6. Kundrapu S, Sunkesula V, Jury LA, Sitzlar BM, Donskey CJ. Daily disinfection of high-touch surfaces in isolation rooms to reduce contamination of healthcare workers' hands. Infect Control Hosp Epidemiol 2012; 33(10): 1039-1042.

7. Deshpande A, Sitzlar B, Fertelli D, et al. Utility of an adenosine triphosphate bioluminescence assay to evaluate disinfection of Clostridium difficile isolation rooms. Infect Control Hosp Epidemiol 2013; 34(8): 865-867. 


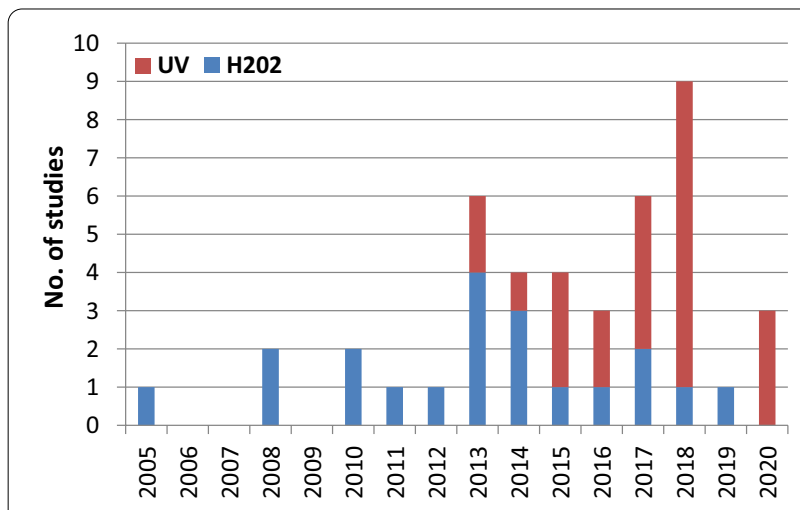

Fig. 2 Year of study (2005-2020) and device type (UVC vs H202) over review period

or in combination with others, was C. difficile (27 of 43 studies: $63 \%$ ), followed by MRSA (16 of 43 : 37\%); MDRA (15 of 43: 35\%); VRE (14 of 43: 33\%) and MDRGN (12 of 43: $28 \%)$. There were 29 of 43 studies (67\%) that also performed before and after sampling of the environment for the same pathogens as monitored for patient infections.
Most studies reported either reductions in HAI rates for the study pathogen(s) or resolution of an outbreak. Some studies reported effects on one or more pathogen rates along with no change or even increases in other pathogen rates. Two studies reported an increase in C.difficile rates using $\mathrm{UV}$ and $\mathrm{H} 2 \mathrm{O} 2[18,32]$ and another reported static rates for $C$. difficile and VRE following UV use in a bone marrow transplant unit [23]. One analysis of the BETR study (using UV) saw a reduction only in VRE and not in rates of infection due to $C$. difficile, MRSA or Acinetobacter, although the latter numbers were so small, the effect could not be analysed [24]. Other C. difficile studies using UV showed no statistically significant decrease over a 25 month period, [28] while at the same time rates decreased for the bone marrow transplant unit in the same hospital; [16] another UV study reported a decline in C. difficile but not for other pathogens including MRSA [31]. Mixed results for UV were also found by Vianna et al., with reductions in $C$. difficile and VRE in the study ICU but increasing MRSA and static VRE rates outside the ICU [35]. One study using UV on a burn

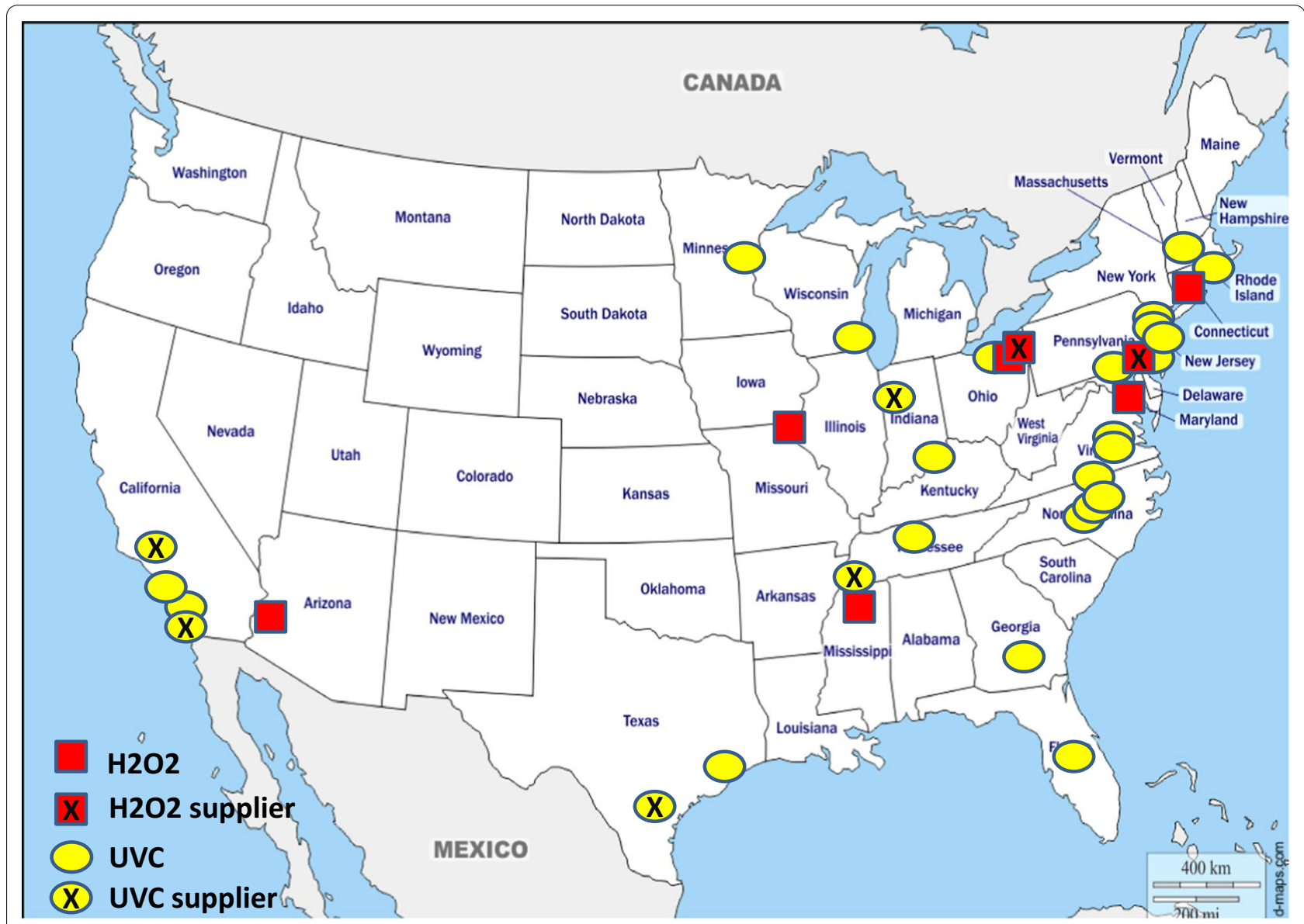

Fig. 3 Location of UV and H2O2 industries and study institutions in the USA 


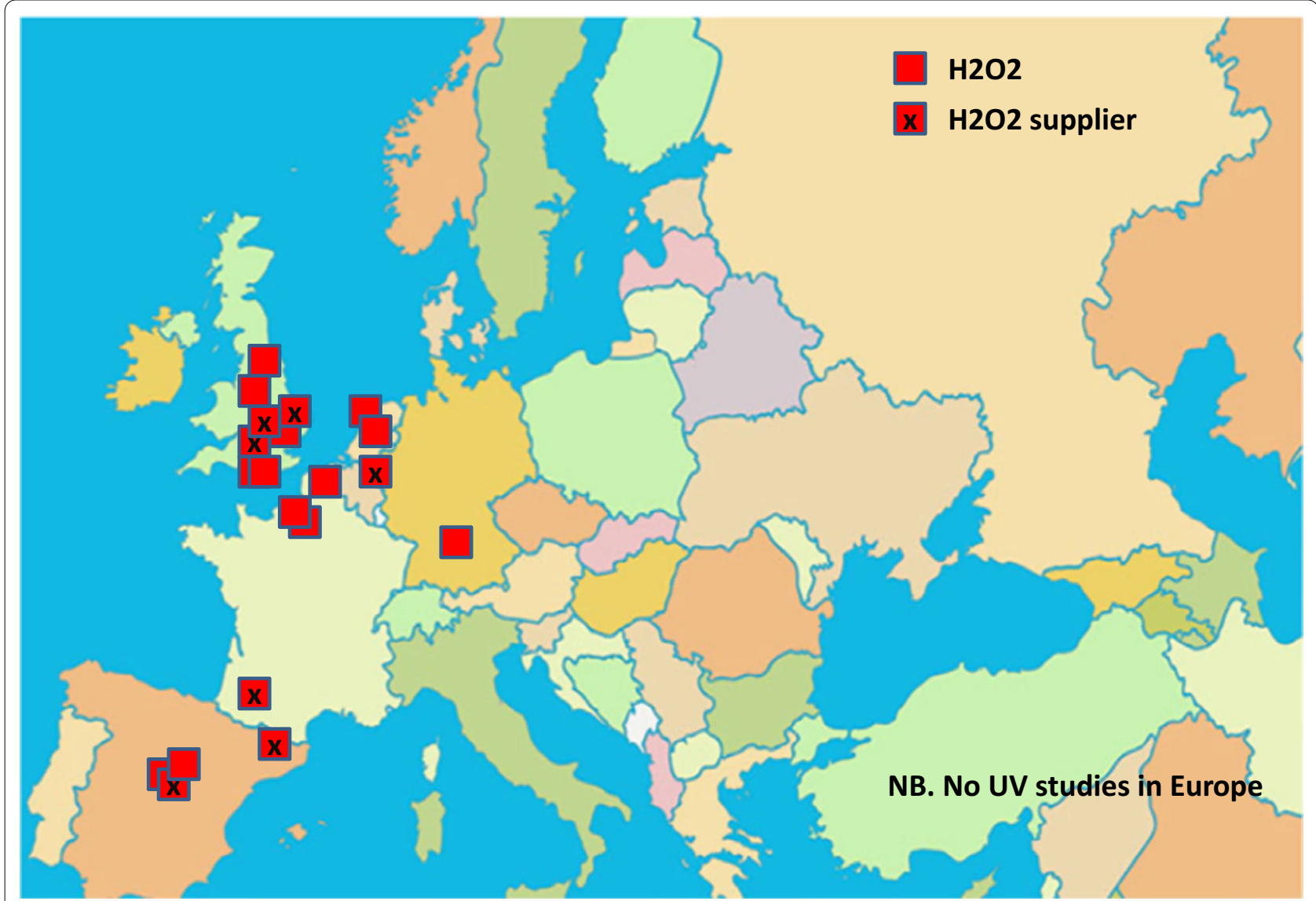

Fig. 4 Location of H2O2 industries and study institutions in Europe

unit found no significant impact on total MDRO, deviceassociated infections or MDRGNs [34]. One study targeted operating theatres and measured the impact of UV on surgical site infection rates; these decreased for 'clean' but not for 'clean contaminated' surgery, which actually increased by $23 \%$ [36]. Several studies saw non-significant effects on MRSA using both $\mathrm{H} 2 \mathrm{O} 2[38,47]$ and UV [39], and another UV study achieved a reduction in $C$. difficile rates only after introducing a supervised cleaning team targeting hand-touch sites with bleach wipes [50]. One protracted outbreak of MDRA reoccurred despite hydrogen peroxide and additional infection control interventions [45] and another recovered the outbreak MDRA from the environment 2-3 weeks after hydrogen peroxide treatment [55].

\section{Common confounders}

\section{Infection prevention and control}

Controlling an environmental decontamination study is fraught with confounders, often due to concurrent or new initiatives in infection prevention and control introduced before, or during, the study. Some authors recognised the importance of these confounders and collected additional data in order to regulate possible conflicting effects, e.g. antimicrobial consumption; hand hygiene; and patient screening. These studies usually discussed the potential impact on overall findings. Others mentioned infection control activities implemented before or during the study without providing any detail or discussion on potential impact; this may have been mandated by a bundled approach during an outbreak or lack of space in a brief publication. Some demonstrated obvious conflicts, such as lack of admission screening, antimicrobial prescribing changes, staff education programmes or use of powerful disinfectants before, or during, device deployment. These studies would have been seriously compromised by such initiatives, when such activities are already known to have a major impact of HAI rates. The studies by Raggi et al. [22] and Haas et al. [43], Ethington et al. [26], Kane et al. [27], McCord et al. [37] and Horn and Otter [38] illustrate a range of pitfalls in a decontamination assessment [59]. Conversely, the articles by Pegues et al. [31] and Brite et al. [23] are good examples of studies that attempted to control confounders. 


\section{Monitoring cleaning and cleanliness}

Cleaning staff are very susceptible to Hawthorne effects when a research study involves sampling general surfaces in the clinical environment [60,61]. One mechanism for controlling changes in compliance by domestic staff is to introduce some type of monitoring; either by measuring cleaning compliance using fluorescent tagging, or by evaluating cleanliness using ATP detection to assess surface levels of organic soil [7]. Other methods involve direct observation of cleaners; supervisory sign-off; check lists; feed-back; and visual monitoring [2]. The microbiological sampling performed in many studies would have had an effect on cleaning staff because this would have been difficult to blind and would have sent out strong messages regarding cleaning efficiency. If cleaning staff detect interest in the work they do, then they usually 'up the game' in order to alleviate any threat toward their jobs [61]. This would have impacted on overall outcome, environmental sampling data and even HAI rates.

There is little, if any, mention of this predictable psychological reaction in any of the studies in this review. Formal monitoring is, however, mentioned in 16 of 43 (37\%) studies, with use of ATP and feedback to cleaning staff as the two most common methods employed (Table 1). One study introduced both ATP and fluorescent gel tagging along with a cleaning check list and new environmental services contractor [43]. Sitzlar et al. used several methods of monitoring in their study; this proved helpful, given that a newly formed cleaning team for $\mathrm{CD}$ patient rooms with supervisory sign off achieved the outcome sought after UV failed to eradicate hospitalacquired C.difficile [50].

\section{Business and industry involvement}

Inevitably, sponsorship issues arise in this review of automated decontamination devices. Environmental cleaning studies are often funded by manufacturers of cleaning agents or disinfection technologies and this encourages potential conflicts of interest and the introduction of real or perceived biases into the evidence base [62]. There are many forms of sponsorship available from business and industry, ranging from full or part study funding; donation or lending of equipment; device discounts; implementation and engineering technicians; scientific support including article writing and statistical analyses; industry personnel with in the research team; study supervision; free education and training; and device maintenance, among others. A total of 28 of 43 (65\%) studies reported some form or other of industry support, with at least 20 of $43(46 \%)$ studies including industry personnel in the authorship (Table 1). Among reported declarations, there were three main companies providing support and authors for 20 of 43 (46\%) studies; these were Bioquell $[37,38,47,49,51,53,54,56-58]$, Xenex [17, 25, 34-36, 41], and Clorox [21, 24, 30, 31].

There is an additional sideways strategy for industry involvement in promoting device evaluation. This comes in the form of sharing authors with specific expertise for independent studies using the same brand of device. These authors are not necessarily employees of the company but may be contracted or asked to provide support such as statistical analysis, writing or laboratory testing. This was evident in studies using UV devices, in particular $[22,26,27,35,36,39,41]$. Another strategy is socalled 'salami slicing', whereby multiple publications are linked with one original study; this is seen with the BETR study, which generated several papers examining whole or partial datasets using different objectives and/or perspectives for analyses [21, 24, 30,63-65]. While none of these approaches necessarily challenge long held editorial standards on plagiarism, they could inflict bias from subtle advertising. Multiple papers from one set of data skew any future metanalyses on efficacy and hence generate uncertainty for scientists, clinical staff and policy makers [66]. Furthermore, Figs. 3 and 4 highlight the geographical relationships between the country of publication and home location of industry supplying the technology; this may well be obvious, but could add bias by encouraging similar studies from one or two countries dominating the literature.

\section{Data on costs}

Very few of the studies in this review offered tangible data on costs. There was no mention of any resources required or cost savings for 24 of 43 (56\%) studies, with 8 (19\%) giving brief mention of the importance of cost benefit without specific data [25-27, 33, 42, 45, 53, 57]. Ten (23\%) studies offered incomplete costings, mostly based on potential savings from cases averted but lacking a balance against costs of the technology used [20,22, 35-37, $41,44,47-49]$. There was just one study (2\%) that provided a complete breakdown of costs incurred alongside costs saved from cases of C.difficile [31]. It is not possible to compare the costs of an outbreak or HAI against overall costs of devices, maintenance, technical needs and implementation without robust data on expenses; healthcare managers need to know the full range of cost benefits when considering all options for infection prevention.

\section{Statistical aberrations}

Comments on statistical findings are shown in Table 1. The most important finding for non-outbreak studies was use of aggregated data that leads to the conclusion that the author wishes to report. This is called Simpson's paradox, where a trend appears to be positive when the 
data is aggregated but negative when it is disaggregated (when examining individual groups or data collections). Several studies amalgamated selected outcomes together in order to achieve statistical significance [21, 22, 26, 29, $30,34,35,39,43,47]$. This clearly skews reporting and future conclusions from metanalyses.

There was also selective reporting, in that some pathogen rates were monitored but no outcome data was offered. Pegues et al. did not provide any VRE data despite using UV devices for VRE patients; Morikane et al. only measured total ACCs and not MRSA or MDRAB from environmental sampling, despite measuring MRSA and MDRAB HAI rates [17, 31].

Several papers presented statistical analysis which were either underpowered [27] or were performed on small numbers of patients [17, 23, 26, 29, 38]; two papers openly acknowledged statistical limitations $[24,40]$.

\section{Discussion}

\section{Design anomalies}

Most of the studies in this review relied upon historical controls or comparison between clinical units with different patient population mixes. A before-and-after or one-size-fits-all design are not sufficiently reliable to present robust evidence for interventions aimed at controlling HAI $[1,12]$. There were also many confounding practices, some of which were mentioned, or actively controlled and even discussed, but there were probably many more that were ignored and indeed, impossible to predict. The BETR study, in particular, attempted to control several potential confounders but failed to deliver incontrovertible results, which might have encouraged a plethora of linked publications [21, 24, 30, 63-65]. These were, perhaps, an attempt to justify implementation of a complex and no doubt costly sponsored study but despite controls and randomisation, adding UV to routine disinfection had little clinical impact, except possibly for VRE acquisition. An accompanying editorial emphasised the need for multimodal strategies for preventing HAI, particularly antimicrobial stewardship, since enhanced disinfection is only one piece of the puzzle [13]. Universal success in controlling healthcare pathogens with automated decontamination equipment is not necessarily guaranteed.

Another study questioned the lower-than-anticipated effectiveness of UV devices in eradicating $C$. difficile [50]. Since there was only $<50 \%$ removal of DAZO fluorescent gel during the mid-part of this study, it was thought that the cleaners had assumed superlative killing from the devices and relaxed their cleaning vigilance. Certainly, these devices are less effective at killing $C$. difficile spores in shaded areas. There was, however, an immediate and dramatic reduction of culture positive rooms during phase 3 of the study. Declining C. difficile from sampled surfaces was attributed not to the UV devices, but to the creation of a 3-person cleaning team, with daily disinfection of high risk sites using bleach, observed monitoring and supervisory sign off by the lead housekeeper [50].

\section{Comparisons between traditional cleaning and use of automated devices}

There have been comparisons between traditional cleaning, with or without disinfectants, and decontamination using automated devices. Manual cleaning with bleach has been compared against several different disinfection methods, including H202, for terminal cleaning of hospital rooms contaminated with $C$. difficile spores [67]. Products were ranked according to $\log 10$ reductions in colony count from contamination to disinfection. While the most effective products were hydrogen peroxide, bleach (1000 ppm chlorine-releasing agent) and peracetic acid wipes, it was concluded that cheaper traditional methods using bleach were just as effective as modern systems. Comparative studies directly comparing disinfection modalities and cost benefits are limited $[3,67]$.

At least five studies compared routine terminal disinfection with UV devices [68-72]. Penno et al. described the effectiveness of a UV-C emitter in 22 hospital discharge rooms in a tertiary care academic hospital and compared it against terminal disinfection [72]. Using a cleanliness standard of $<5 \mathrm{cfu} / \mathrm{cm}^{2}$ for selected handtouch sites, there were no differences between observed routine disinfection and use of UV-C. Previous studies have shown that non-covert observation of cleaners usually improves housekeeper disinfection [60, 61]. It is likely that carefully constructed standard operating procedures for cleaning staff, along with sufficient time, supervision and monitoring, represents the most cost effective strategy for protecting patients from HAI. Supervisors should tailor job requirements against staffing resources and cleaners should be supported, trained and adequately renumerated [2].

While patient and staff perceptions toward decontamination devices tend to be quite positive, the paucity of evidence for cost-benefit in this review challenges healthcare economists to recommend such technology for routine use [73]. This is not just because the devices are expensive. The equipment can generally only be used after the patient's discharge because patients and staff must vacate the room. However, near-patient sites constitute the highest risk as pathogen reservoirs and these need cleaning every day. [2] For 'long stay' patients, manual cleaning is the only option unless the patients are moved out of their rooms on a daily basis. This means that automated technology for room disinfection can only supplement, not replace, daily cleaning, which 
essentially means retention, rather than replacement, of the domestic workforce [74]. Thus, there is little opportunity for managers to off-set labour savings following device purchase, particularly when non-manual devices are unable to dispose of rubbish or deal with visible soil [11].

\section{Collateral damage}

There are additional issues to consider for these devices. Despite initial eradication of surface flora in exposed areas, we know that surfaces are rapidly recolonised by environmental organisms within hours, including pathogens [75]. Secondly, the resources required to install, run and maintain these devices are considerable, even for hospitals in developed countries [14]. Low income countries might struggle to afford their use on a regular basis. Thirdly, the decontamination effect is not uniform, given that $\mathrm{H} 202$ cannot penetrate linen and soft furnishings and UV misses shaded areas. Neither product delivers expected outcome without first removing surface soil [11, 76].

There are further concerns over the long term impact of these devices, particularly if used on general wards rather than specialist units or when there is less risk of healthcare pathogen transmission. In common with all powerful disinfectants, they damage the environment in ways that we cannot always see. Both H202 and UV are toxic to people, pets and plants. [11] Adverse effects include the formation of high concentrations of hydroxyl and chlorine radicals, which encourage harmful reaction products when exposed to other chemicals found in indoor air [77]. Microbes themselves may survive noxious emissions from UV and H202 devices, which may be linked with emerging tolerance, resistance and crossresistance among environmental pathogens [78-82]. For example, insufficient $\mathrm{H} 202$ would, as with bleach, activate microbial 'SOS' mechanisms, which encourage formation of new, or re-emergence of dormant, survival mechanisms. These facilitate DNA transfer to neighbouring organisms in a veritable shower of plasmid (and other genetic) exchanges coding for resistance to environmental assault [83].

UV light can cause bacterial mutations from a distance [81]. Laboratory trials of UV-A and UV-B exposure highlight the ability of microbial communities to enhance their radiation resistance over time if they are insufficiently exposed [84]. This suggests that resistance to UV-C is highly likely without contained use and surveillance. Microbial communities adapt, reassemble, and persist, and recent theory in microbial ecology suggests that more gentle manipulation of the healthcare surface microbiome may be more sustainable than perpetual attempts at total removal $[11,82]$.
There is additional suspicion that introducing enhanced use of powerful disinfectants can release viable pathogens enmeshed in hard surface biofilm [85]. These organisms have been previously captured in microscopic crevices and their release reflects or even stimulates re-emergence of a previous outbreak [86, 87]. The biofilm lifestyles of microorganisms present a high risk for horizontal gene transfer, with transmission of antibiotic resistance and future recurrence [88]. Given these findings, routine use of microbiocidal products, including H202 and UV light, should be challenged [89].

\section{Universal standards and regulation}

It has already been mentioned that there is no regulation of automated decontamination devices [79]. Chemical disinfectants used in the UK and Europe undergo stringent regulation by the European Chemicals Agency (ECHA) and by the Environmental Protection Agency (EPA) in the USA. Registration of a disinfectant against a given pathogen requires proof of efficacy using standardized test methods. Decontamination devices have not yet been regulated and consequently companies have engineered several different methods to demonstrate efficacy. This is less of a problem for hydrogen peroxide, because it has already been tested as a liquid disinfectant, albeit in different formulations to device-generated aerosol or vapour. UV technologies have not been standardized and this has created concern over in-use variations that have a substantial impact on measuring pathogen reduction, let alone any other effects. Factors such as shadowing; distance from UV source; targeted surface area; carrier orientation; and presence and type of organic material all affect the overall efficacy of UV devices [79, 90]. If these devices become commonplace for universal healthcare, they should undergo standardized testing to receive registration against different pathogens. This would provide consumers with a modicum of assurance that products are effective as well as encourage urgently needed costbenefit evaluation. This is clearly in the interests of business and industry as well as healthcare.

\section{Conclusion}

It was felt timely to independently review all available studies reporting an effect on HAI rates attributed to automated devices dispelling UV or H202. This systematic review is not just an assimilation of the clinical effects from these devices but a critical expose of the methods and pitfalls uncovered in the majority of studies reporting use. Device technologies offer a solution to just one aspect of infection prevention; this is because antimicrobial stewardship, isolation, hand hygiene and screening have already earned their place as useful strategies to control infection and all have been shown to 
reduce HAI rates $[13,91]$. Doubtless there are yet more activities that can be added. It may be tempting to engage with modern technology when confronting HAI risks from environmental contamination, especially during an outbreak, but the findings in this review cannot support automated devices as a reliable alternative to manual and basic housekeeping practices. Current cleaning advice for occupied bed spaces, 'One wipe; one site; and one direction', with detergent and water, is easy, cheap and effective; and will not upset the surface ecology or create a futuristic 'superbug' [82, 92]. We should continue to support traditional infection control practices, including cleaning, without undue reliance on novel technology at the present time. [18].

\section{Acknowledgements}

SJD wishes to acknowledge the support provided by NHS Lanarkshire Research \& Development and School of Applied Sciences, Edinburgh Napier University, Scotland.

\section{Authors' contributions}

SJD conceived the review subject, conducted the literature search, analysed data and drafted the text; MFK reviewed articles, added statistical analysis and constructed figures; both authors agreed the final text. Both authors read and approved the final manuscript.

\section{Funding}

No funding was received for the writing of this review.

\section{Competing interests}

The authors declare that they have no competing interests.

\section{Author details}

${ }^{1}$ Department of Microbiology, Hairmyres Hospital, NHS, Lanarkshire G75 8RG, Scotland, UK. ${ }^{2}$ School of Applied Sciences, Edinburgh Napier University, Edinburgh, Scotland, UK. ${ }^{3}$ School of Civil Engineering, University of Leeds, Leeds, UK.

Received: 21 August 2020 Accepted: 21 January 2021

Published online: 12 February 2021

\section{References}

1. Marra AR, Schweizer ML, Edmond MB. No-touch disinfection methods to decrease multidrug-resistant organism infections: a systematic review and meta-analysis. Infect Control Hosp Epidemiol. 2018;39(1):20-31.

2. Dancer SJ. Controlling hospital-acquired infection: focus on the role of the environment and new technologies for decontamination. Clin Microbiol Rev. 2014;27(4):665-90.

3. Weber DJ, Kanamori H, Rutala WA. 'No touch'technologies for environmental decontamination: focus on ultraviolet devices and hydrogen peroxide systems. Curr Opin Infect Dis. 2016;29:424-31.

4. Tarka P, Nitsch-Osuch A. No-touch automated disinfection system for decontamination of surfaces in hospitals. Int J Environ Res Public Health. 2020;17:5131

5. Cabral J, Ag R. Blue Light Disinfection in Hospital Infection Control: Advantages, Drawbacks, and Pitfalls. Antibiotics (Basel) 2019 May 7; 8(2).

6. Fu TY, Gent P, Kumar V. Efficacy, efficiency and safety aspects of hydrogen peroxide vapour and aerosolized hydrogen peroxide room disinfection systems. J Hosp Infect. 2012;80:199-205.

7. Carling PC, Huang SS. Improving healthcare environmental cleaning and disinfection: current and evolving issues. Infect Control Hosp Epidemiol. 2013;34:507-13.

8. Dancer SJ. Do's and Don'ts for hospital cleaning. Curr Opin Infect Dis. 2016;29(4):415-23.
9. Boyce JM. Modern technologies for improving cleaning and disinfection of environmental surfaces in hospitals. Antimicrob Resist Infect Control. 2016;5:10.

10. Carling PC. The need for clinically relevant studies of non-touch disinfecting systems. J Hosp Infect. 2013;84:340.

11. Dancer SJ. Floor Wars: The Battle for 'Clean' surfaces. J Hosp Infect. 2013;84:339-40.

12. Harris AD, Lautenbach E, Perencevich E. A systematic review of quasiexperimental study designs in the fields of infection control and antibiotic resistance. Clin Infect Dis. 2005;41:77-82.

13. Crotty MP, Wilson MH. Enhanced terminal room disinfection and the need for multimodal collaboration. Lancet Infect Dis. 2018;18(8):814-5.

14. Health Quality Ontario. Portable ultraviolet light surface-disinfecting devices for prevention of hospital-acquired infections: a health technology assessment. Ont Health Technol Assess Ser 2018; 18(1):1-73. eCollection 2018.

15. Hooker EA. Increased time spent on terminal cleaning of patient rooms may not improve disinfection of high-touch surfaces. Infect Control Hosp Epidemiol. 2019;40(9):1086.

16. Murphy P, Kang L, Fleming M, Atkinson C, Pryor R, Cooper K, Godbout E, Stevens MP, Doll M, Bearman G. Effect of ultraviolet-C light disinfection at terminal patient discharge on hospital-acquired infections in bone marrow transplant and oncology units. Am J Infect Control 2020; in press.

17. Morikane K, Suzuki S, Yoshioka J, Yakuwa J, Nakane M, Nemoto K. Clinical and microbiological effect of pulsed xenon ultraviolet disinfection to reduce multidrug-resistant organisms in the intensive care unit in a Japanese hospital: a before-after study. BMC Infect Dis. 2020;20(1):82

18. Attia F, Whitener C, Mincemoyer S, Houck J, Julian K. The effect of pulsed xenon ultraviolet light disinfection on healthcare-associated Clostridioides difficile rates in a tertiary care hospital. Am J Infect Control 2020; in press.

19. García-Arenzana N, Redondo-Bravo L, Espinel-Ruiz MA, Borrego-Prieto P, Ruiz-Carrascoso G, Quintas-Viqueira A, Sanchez-Calles A, RobustilloRodela A. Carbapenem-resistant enterobacteriaceae outbreak in a medical ward in Spain: epidemiology, control strategy, and importance of environmental disinfection. Microb Drug Resist. 2020;26(1):54-9.

20. Frakking FNJ, Bril WS, Sinnige JC, Klooster JEV, de Jong BAW, van Hannen EJ, Tersmette M. Recommendations for the successful control of a large outbreak of vancomycin-resistant Enterococcus faecium in a non-endemic hospital setting. J Hosp Infect. 2018;100(4):e216-25.

21. Rutala WA, Kanamori H, Gergen MF, Knelson LP, Sickbert-Bennett EE, Chen LF, Anderson DJ, Sexton DJ, Weber DJ, The CDC Prevention Epicenters Program. Enhanced disinfection leads to reduction of microbial contamination and a decrease in patient colonization and infection. Infect Control Hosp Epidemiol. 2018;39(9):1118-21.

22. Raggi R, Archulet K, Haag CW, Tang W. Clinical, operational, and financial impact of an ultraviolet- $C$ terminal disinfection intervention at a community hospital. Am J Infect Control. 2018;46(11):1224-9.

23. Brite J, McMillen T, Robilotti E, Sun J, Chow HY, Stell F, Seo SK, McKenna D, Eagan J, Montecalvo M, Chen D, Sepkowitz K, Kamboj M. Effectiveness of ultraviolet disinfection in reducing hospital-acquired Clostridium difficile and vancomycin-resistant Enterococcus on a bone marrow transplant unit. Infect Control Hosp Epidemiol. 2018;39(11):1301-6.

24. Anderson DJ, Moehring RW, Weber DJ, Lewis SS, Chen LF, Schwab JC, Becherer P, Blocker M, Triplett PF, Knelson LP, Lokhnygina Y, Rutala WA, Sexton DJ, CDC Prevention Epicenters Program. Effectiveness of targeted enhanced terminal room disinfection on hospital-wide acquisition and infection with multidrug-resistant organisms and Clostridium difficile: a secondary analysis of a multicentre cluster randomised controlled trial with crossover design (BETR Disinfection). Lancet Infect Dis. 2018;18(8):845-53.

25. Sampathkumar P, Folkert C, Barth JE, Nation L, Benz M, Hesse A, Mielke Ms $\mathrm{CL}$, Zaveleta KW. A trial of pulsed xenon ultraviolet disinfection to reduce Clostridioides difficile infection. Am J Infect Control. 2019;47(4):406-8.

26. Ethington T, Newsome S, Waugh J, Lee LD. Cleaning the air with ultraviolet germicidal irradiation lessened contact infections in a long-term acute care hospital. Am J Infect Control. 2018;46(5):482-6.

27. Kane DW, Finley C, Brown D. UV-C light and infection rate in a long term care ventilator unit. Can J Infect Control. 2018;33:44-8.

28. Fleming M, Patrick A, Gryskevicz M, Masroor N, Hassmer L, Shimp K, Cooper K, Doll M, Stevens M, Bearman G. Deployment of a touchless 
ultraviolet light robot for terminal room disinfection: The importance of audit and feedback. Am J Infect Control. 2018;46(2):241-3.

29. Kovach CR, Taneli Y, Neiman T, Dyer EM, Arzaga AJ, Kelber ST. Evaluation of an ultraviolet room disinfection protocol to decrease nursing home microbial burden, infection and hospitalization rates. BMC Infect Dis. 2017;17(1):186.

30. Anderson DJ, Chen LF, Weber DJ, Moehring RW, Lewis SS, Triplett PF, Blocker M, Becherer P, Schwab JC, Knelson LP, Lokhnygina Y, Rutala WA, Kanamori H, Gergen MF, Sexton DJ, CDC Prevention Epicenters Program. Enhanced terminal room disinfection and acquisition and infection caused by multidrug-resistant organisms and Clostridium difficile (the Benefits of Enhanced Terminal Room Disinfection study): a cluster-randomized, multicentre crossover study. Lancet. 2017;389:805-14.

31. Pegues DA, Han J, Gilmar C, McDonnell B, Gaynes S. Impact of ultraviolet germicidal irradiation for no-touch terminal room disinfection on Clostridium difficile infection incidence among hematology-oncology patients. Infect Control Hosp Epidemiol. 2017;38:39-44.

32. Yui S, Ali S, Muzslay M, Jeanes A, Wilson APR. Identification of Clostridium difficile reservoirs in the patient environment and efficacy of aerial hydrogen peroxide decontamination. Infect Control Hosp Epidemiol. 2017;38(12):1487-92.

33. Robustillo-Rodela A, Pérez-Blanco V, Espinel Ruiz MA, Ruiz Carrascoso G, Figueira Iglesias JC, Abad MD. Successful control of 2 simultaneous outbreaks of OXA-48 carbapenemase-producing Enterobacteriaceae and multidrug-resistant Acinetobacter baumannii in an intensive care unit. Am J Infect Control. 2017;45(12):1356-62.

34. Green C, Pamplin JC, Chafin KN, Murray CK, Yun HC. Pulsed-xenon ultraviolet light disinfection in a burn unit: impact on environmental bioburden, multidrug-resistant organism acquisition and healthcare associated infections. Burns. 2017;43(2):388-96.

35. Vianna PG, Dale CR Jr, Simmons S, Stibich M, Licitra CM. Impact of pulsed xenon ultraviolet light on hospital-acquired infection rates in a community hospital. Am J Infect Control. 2016;44(3):299-303.

36. Catalanotti A, Abbe D, Simmons S, Stibich M. Influence of pulsed-xenon ultraviolet light-based environmental disinfection on surgical site infections. Am J Infect Control. 2016;44(6):e99-101.

37. McCord J, Prewitt M, Dyakova E, Mookerjee S, Otter JA. Reduction in Clostridium difficile infection associated with the introduction of hydrogen peroxide vapour automated room disinfection. J Hosp Infect. 2016;94(2):185-7.

38. Horn K, Otter JA. Hydrogen peroxide vapor room disinfection and hand hygiene improvements reduce Clostridium difficile infection, methicillinresistant Staphylococcus aureus, vancomycin-resistant enterococci and extended-spectrum b-lactamase. Am J Infect Control. 2015;43:1354-6.

39. Napolitano NA, Mahapatra T, Tang W. The effectiveness of UV-C radiation for facility-wide environmental disinfection to reduce health careacquired infections. Am J Infect Control. 2015:43(12):1342-6.

40. Nagaraja A, Visintainer P, Haas JP, Menz J, Wormser GP, Montecalvo MA. Clostridium difficile infections before and during use of ultraviolet disinfection. Am J Infect Control. 2015;43(9):940-5.

41. Miller R, Simmons S, Dale C, Stachowiak J, Stibich M. Utilization and impact of a pulsed-xenon ultraviolet room disinfection system and multidisciplinary care team on Clostridium difficile in a long-term acute care facility. Am J Infect Control. 2015;43:1350-3.

42. Mitchell BG, Digney W, Locket P, Dancer SJ. Controlling methicillin-resistant Staphylococcus aureus (MRSA) in a hospital and the role of hydrogen peroxide decontamination: an interrupted time series analysis. BMJ Open. 2014:4(4):e004522.

43. Haas JP, Menz J, Dusza S, Montecalvo MA. Implementation and impact of ultraviolet environmental disinfection in an acute care setting. Am J Infect Control. 2014;42:586-90.

44. Best EL, Parnell P, Thirkell G, Verity P, Copland M, Else P, Denton M, Hobson RP, Wilcox MH. Effectiveness of deep cleaning followed by hydrogen peroxide decontamination during high Clostridium difficile infection incidence. J Hosp Infect. 2014;87(1):25-33.

45. Alfandari S, Gois J, Delannoy PY, Georges H, Boussekey N, Chiche A, Meybeck A, Patoz P, Blondiaux N, Senneville E, Melliez H, Leroy O. Management and control of a carbapenem-resistant Acinetobacter baumanni outbreak in an intensive care unit. Med Mal Infect. 2014;44(5):229-31.

46. Landelle $C$, Legrand $P$, Lesprit $P$, Cizeau F, Ducellier D, Gouot C, Bréhaut P, Soing-Altrach S, Girou E, Brun-Buisson C. Protracted outbreak of multidrug-resistant Acinetobacter baumannii after intercontinental transfer of colonized patients. Infect Control Hosp Epidemiol. 2013;34(2):119-24

47. Passaretti CL, Otter JA, Reich NG, Myers J, Shepard J, Ross T, Carroll KC, Lipsett P, Perl TM. An evaluation of environmental decontamination with hydrogen peroxide vapor for reducing the risk of patient acquisition of multidrug-resistant organisms. Clin Infect Dis. 2012;56:27-35.

48. Levin J, Riley LS, Parrish C, English D, Ahn S. The effect of portable pulsed xenon ultraviolet light after terminal cleaning on hospital-associated Clostridium difficile infection in a community hospital. Am J Infect Control. 2013;41:746-8.

49. Manian FA, Griesnauer S, Bryant A. Implementation of hospital wide enhanced terminal cleaning of targeted patient rooms and its impact on endemic Clostridium difficile infection rates. Am J Infect Control. 2013:41:537-41.

50. Sitzlar B, Deshpande A, Fertelli D, Kundrapu S, Sethi AK, Donskey CJ. An environmental disinfection odyssey: evaluation of sequential interventions to improve disinfection of Clostridium difficile isolation rooms. Infect Control Hosp Epidemiol. 2013;34(5):459-65.

51. Barbut F, Yezli S, Mimoun M, Pham J, Chaouat M, Otter JA. Reducing the spread of Acinetobacter baumannii and methicillin-resistant Staphylococcus aureus on a burns unit through the intervention of an infection control bundle. Burns. 2013;39(3):395-403.

52. Chmielarczyk A, Higgins PG, Wojkowska-Mach J, Synowiec E, Zander E, Romaniszyn D, Gosiewski T, Seifert H, Heczko P, Bulanda M. Control of an outbreak of Acinetobacter baumannii infections using vaporized hydrogen peroxide. J Hosp Infect. 2012;81 (4):239-45.

53. Cooper T, O'Leary M, Yezli S, Otter JA. Impact of environmental decontamination using hydrogen peroxide vapour on the incidence of Clostridium difficile infection in one hospital Trust. J Hosp Infect. 2011;78:238-40.

54. Otter JA, Yezli S, Schouten MA, van Zanten AR, Houmes-Zielman G, Nohlmans-Paulssen MK. Hydrogen peroxide vapour decontamination of an intensive care unit to remove environmental reservoirs of multidrugresistant gram-negative rods during an outbreak. Am J Infect Control. 2010;38(9):754-6.

55. Ray A, Perez F, Beltramini AM, Jakubowycz M, Dimick P, Jacobs MR, Roman K, Bonomo RA, Salata RA. Use of vaporized hydrogen peroxide decontamination during an outbreak of multidrug-resistant Acinetobacter baumannii infection at a long-term acute care hospital. Infect Control Hosp Epidemiol. 2010;31(12):1236-41.

56. Dryden M, Parnaby R, Dailly S, Lewis T, Davis-Blues K, Otter JA, Kearns AM. Hydrogen peroxide vapour decontamination in the control of a polyclonal meticillin-resistant Staphylococcus aureus outbreak on a surgical ward. J Hosp Infect. 2008;68(2):190-2.

57. Boyce JM, Havill NL, Otter JA, McDonald LC, Adams NM, Cooper T, Thompson A, Wiggs L, Killgore G, Tauman A, Noble-Wang J. Impact of hydrogen peroxide vapor room decontamination on Clostridium difficile environmental contamination and transmission in a healthcare setting. Infect Control Hosp Epidemiol. 2008;29:723-9.

58. Bates CJ, Pearse R. Use of hydrogen peroxide vapour for environmental control during a Serratia outbreak in a neonatal intensive care unit. J Hosp Infect. 2005;61(4):364-6.

59. De Kraker M, Harbarth S, Dancer SJ. Shining a light on ultraviolet-C disinfection: no golden promises for infection prevention. Am J Infect Control. 2018:46(12):1422-3.

60. Hayden MK, Bonten MJ, Blom DW, Lyle EA, van de Vijver DA, Weinstein RA. Reduction in acquisition of vancomycin-resistant Enterococcus after enforcement of routine environmental cleaning measures. Clin Infect Dis. 2006:42:1552-60

61. Dancer SJ. Hospital cleaning in the 21st century. Eur J Clin Microbiol Infect Dis. 2011;30:1473-81.

62. Leas BF, Sullivan N, Han JH, Pegues DA, Kaczmarek JL, Umscheid CA. Environmental cleaning for the prevention of healthcare-associated infections. Agency for Healthcare Research and Quality, Rockville (MD) (2015) Report No.: 15-EHC020-EF. AHRQ Comparative Effectiveness Technical Briefs.

63. Chen LF, Knelson LP, Gergen MF, Better OM, Nicholson BP, Woods CW, Rutala WA, Weber DJ, Sexton DJ, Anderson DJ. A prospective study of transmission of Multidrug-Resistant Organisms (MDROs) between environmental sites and hospitalized patients-the TransFER study. Infect Control Hosp Epidemiol. 2019;40(1):47-52. 
64. Anderson DJ, Knelson LP, Moehring RW, Lewis SS, Weber DJ, Chen LF, Triplett PF, Blocker M, Cooney RM, Schwab JC, Lokhnygina Y, Rutala WA, Sexton DJ, CDC Prevention Epicenters Program. Implementation Lessons Learned From the Benefits of Enhanced Terminal Room (BETR) disinfection study: process and perceptions of enhanced disinfection with ultraviolet disinfection devices. Infect Control Hosp Epidemiol. 2018;39(2):157-63.

65. Knelson LP, Ramadanovic GK, Chen LF, Moehring RW, Lewis SS, Rutala WA, Weber DJ, Sexton DJ, Anderson DJ, CDC Prevention EpiCenters Program. Self-monitoring by Environmental Services may not accurately measure thoroughness of hospital room cleaning. Infect Control Hosp Epidemiol. 2017;38(11):1371-3.

66. Smith R. The Trouble with Medical Journals. Royal Society of Medicine Press, 2006. ISBN: 978-1-85315-673-1.

67. Doan L, Forrest H, Fakis A, Craig J, Claxton L, Khare M. Clinical and cost effectiveness of eight disinfection methods for terminal disinfection of hospital isolation rooms contaminated with Clostridium difficile 027. J Hosp Infect. 2012;82(2):114-21.

68. Beal A, Mahida N, Staniforth K, Vaughan N, Clarke M, Boswell T. First UK trial of Xenex PX-UV, an automated ultraviolet room decontamination device in a clinical haematology and bone marrow transplantation unit. J Hosp Infect. 2016;93:164-8.

69. Hosein I, Madeloso R, Nagaratnam W, Villamaria F, Stock E, Jinadatha C. Evaluation of a pulsed xenon ultraviolet light device for isolation room disinfection in a United Kingdom hospital. Am J Infect Control. 2016;44:157-61.

70. Jinadatha C, Quezada R, Huber T, Williams J, Zeber J, Copeland L. Evaluation of a pulsed-xenon ultraviolet room disinfection device for impact on contamination levels of methicillin-resistant Staphylococcus aureus. BMC Infect Dis. 2014;14:187.

71. Nerandzic M, Cadnum J, Pultz M, Donskey C. Evaluation of an automated ultraviolet radiation device for decontamination of Clostridium difficile and other healthcare-associated pathogens in hospital rooms. BMC Infect Dis. 2010;10:197.

72. Penno K, Jandarov RA, Sopirala MM. Effect of automated ultraviolet C-emitting device on decontamination of hospital rooms with and without real-time observation of terminal room disinfection. Am J Infect Control. 2018;45:1208-13.

73. Dunn AN, Vaisberg P, Fraser TG, Donskey CJ, Deshpande A. Perceptions of patients, health care workers, and environmental services staff regarding ultraviolet light room decontamination devices. Am J Infect Control. 2019;47(11):1290-3.

74. Barbut F. How to eradicate Clostridium difficile from the environment. J Hosp Infect. 2015;89(4):287-95.

75. Hardy KJ, Gossain S, Henderson N, Drugan C, Oppenheim BA, Gao F, Hawkey PM. Rapid recontamination with MRSA of the environment of an intensive care unit after decontamination with hydrogen peroxide vapour. J Hosp Infect. 2007;66:360-8.

76. Cadnum JL, Tomas ME, Sankar T, Jencson A, Mathew Jl, Kundrapu S, et al. Effect of variation in test methods on performance of ultravioletC radiation room decontamination. Infect Control Hosp Epidemiol. 2016;37:555-60.
77. Wang Z, Kowal SF, Carslaw N, Kahan TF. Photolysis driven indoor air chemistry following cleaning of hospital wards. Indoor Air 2020; in press.

78. European Commission. Assessment of the antibiotic resistance effects of biocides. European Commission, Brussels, Belgium (2009). https ://ec.europa.eu/health/ph_risk/committees/04_scenihr/docs/sceni hr_o_021.pdf.

79. Sattar SA. Promises and pitfalls of recent advances in chemical means of preventing the spread of nosocomial infections by environmental surfaces. Am J Infect Control. 2010;38(5 Suppl 1):S34-40.

80. Kampf G. Challenging biocide tolerance with antiseptic stewardship. J Hosp Infect. 2018;100:e37-9.

81. Mora M, Mahnert A, Koskinen K, Pausan MR, Oberauner-Wappis L, Krause R, Perras AK, Gorkiewicz G, Berg G, Moissl-Eichinger C. Microorganisms in confined habitats: microbial monitoring and control of intensive care units, operating rooms, cleanrooms and the international space station. Front Microbiol. 2016;7:1573 (eCollection 2016).

82. Velasquez S, Griffiths W, Dietz L, Horve P, Nunez S, Hu J, Shen J, Fretz M, Bi C, Xu Y, Van Den Wymelenberg KG, Hartmann EM, Ishaq SL. From one species to another: a review on the interaction between chemistry and microbiology in relation to cleaning in the built environment. Indoor Air. 2019;29(6):880-94.

83. de Bruijn FJ. Stress and Environmental Regulation of Gene Expression and Adaptation in Bacteria, I\&ll. New York: Wiley; 2016. https://doi. org/10.1002/9781119004813.

84. Goldman RP, Travisano M. Experimental evolution of ultraviolet radiation resistance in Escherichia coli. Evolution. 2011;65:3486-98.

85. Stewart M, Bogusz A, Hunter J, Devanny I, Yip B, Reid D, Robertson C, Dancer SJ. Microbiological effect of cleaning near-patient sites with electrolysed water. Infect Control Hosp Epidemiol. 2014;35(12):1505-10.

86. Kramer A, Schwebke I, Kampf G. How long do nosocomial pathogens persist on inanimate surfaces? A systematic review. BMC Infect Dis. 2006;6:130.

87. Vickery K, Deva A, Jacombs A, Allan J, Valente P, Gosbell I. Presence of biofilm containing viable multiresistant organisms despite terminal cleaning on clinical surfaces in an intensive care unit. J Hosp Infect. 2012;80:52-5.

88. Fux CA, Costerton JW, Stewart PS, Stoodley P. Survival strategies of infectious biofilms. Trends Microbiol. 2005;13:34-40.

89. Curran ET, Wilkinson M, Bradley T. Chemical disinfectants: controversies regarding their use in low risk healthcare environments (part 1). J Infect Prevent. 2019;20(2):76-82.

90. Donskey CJ. Decontamination devices in health care facilities: practical issues and emerging applications. Am J Infect Control. 2019;47:A23-8.

91. Dancer SJ. Infection control; evidence-based common sense. Infect Dis Health. 2016;21(4):147-53.

92. Dancer SJ, Kramer A. Four steps to clean hospitals: look; plan, clean; and dry. J Hosp Infect. 2019;103(1):e1-8.

\section{Publisher's Note}

Springer Nature remains neutral with regard to jurisdictional claims in published maps and institutional affiliations.

Ready to submit your research? Choose BMC and benefit from

- fast, convenient online submission

- thorough peer review by experienced researchers in your field

- rapid publication on acceptance

- support for research data, including large and complex data types

- gold Open Access which fosters wider collaboration and increased citations

- maximum visibility for your research: over 100M website views per year

At BMC, research is always in progress.

Learn more biomedcentral.com/submissions 